\title{
Language and the novel in globalization
}

\author{
João Vianney Cavalcanti Nuto ${ }^{1}$
}

\begin{abstract}
Resumo: Este ensaio aborda questões linguísticas e culturais associados à globalização, à língua e ao gênero romance, a fim de demonstrar que esse gênero literário pode expressar as tensões da globalização. A principal base teórica é o pensamento de Mikhail Bakhtin. No que diz respeito a linguagem este trabalho inicia-se chamando a atenção para a discrepância entre o pensamento lingüístico do círculo de Bakhtin e a Lingüística Estrutural de Ferdinand de Saussure, enfatizando que os estudos linguísticos baseados no enunciado permitem uma ligação adequada entre o sistema linguístico e a vida social. O ensaio explica a distinção, por Bakhtin, entre forças centrípetas e centrífugas da linguagem e sua relação com a globalização. Ele também explica o conceito do romance de Bakhtin, destacando a relação do gênero como pluralidade dialógica dos discursos, a fim de demonstrar a adequação do romance para representar o mundo globalizado. Teorias da globalização são confrontadas e os problemas relacionados com a globalização são expostos. Seguindo o pensamento de Milton Santos, este ensaio reflete sobre a possibilidade de uma outra globalização, não só expansiva, mas também integrativa. Ao comentar a situação cultural de certos escritores e as suas tentativas de expressá-la, este ensaio combina pensamento de Bakhtin com as teorias da globalização, a fim de apontar possíveis respostas do romance contemporâneo.
\end{abstract}

Palavras-chave: Mikhail Bakhtin; Linguística; discurso; romance; globalização.

\begin{abstract}
This essay approaches linguistic and cultural issues associated with globalization, language and the novel in order to demonstrate how the novel as a literary genre can express the tensions of globalization. The main theoretical basis is Mikhail Bakhtin's theory of language and the novel. Concerning language the paper recalls the discrepancy between the linguistic thought of Bakhtin's circle and the structural linguistics by Ferdinand de Saussure, emphasizing that a linguistic based on utterance enables a suitable link between structural system and society. The paper explains the difference between centripetal and centrifugal forces of language, according to Bakhtin and their relationship with globalization. It also explains Bakhtin's concept of the novel, stressing the relationship of the genre as a dialogic plurality of discourses, in order to demonstrate how suitable the novel is to express the globalized world. Theories of globalization are confronted and the problems related to globalization are exposed. Following Milton Santo's thought, the paper reflects on the possibility of another
\end{abstract}

1 Professor of Theory of Literature at Universidade de Brasília (Brazil), Ph.D. in Comparative Studies of Literature in Portuguese Language and coordinator of research group Literature and Culture. Presently he focuses his studies and courses on the philosophy of the Circle of Mikhail Bakhtin and in the literary achievement of Brazilian writer Osman Lins. 
globalization, not only expansive, but also integrative. By commenting the cultural situation of certain writers and their attempts to express it, this essay combines Bakhtin's thought with theories of globalization in order to point out possible responses of contemporary novel.

Keywords: Mikhail Bakhtin; linguistics; discourse; literaty genres; novel; globalization.

Dealing with language and literature in the globalized world requires a transdisciplinary approach, for such a context involves political, anthropological, economic and sociological issues, among other ones. I do not intend to exhaust the theme, much less to cover all the disciplines which such topic demands. Instead, I rely on Mikhail Bakhtin's theory to analyze the possibilities of response of the novel to the globalized context. The theoretical achievement of Mikhail Bakhtin and his circle has proved to be increasingly relevant not only to Linguistics and Literary Studies, but also to Human Sciences in general, as the result of an intellectual activity which is not limited within a scientific field, but placed, as Bakhtin (2006) states, in the boundaries of different sciences.

Beginning his reflections in a historical moment whose priority was either to set strictly the boundaries of the literary discourse or to study literature as a direct result of economic factors, Bakhtin (2003. p. 360) emphasized the need to study the relationship between Literature and other elements of culture. Therefore, he suggests an approach which may be termed "anthropological". Concerning the study of language, Bakhtin surpasses the structural analysis and explores the domain of utterance. Thus he explores profoundly the social nature of language already observed but never explored by Ferdinand de Saussure. Indeed such conception of language is fundamental for the study of discourses in globalization because utterances associated to discourse genres articulate the linguistic system with the social environment.

Based on the reflections of Bakhtin and his circle, I proceed to analyze the tension between linguistic unification forces (centripetal forces) and linguistic stratification ones (centrifugal forces), as well as the dialogism involved in such tension; the characteristics of the novel according to Bakhtin, as a response to certain social conditions; the linguistic and ideological situation in contemporaneity an its perception by novelists in the globalized world; and the possible aesthetic-ideological responses in the novel.

Ferdinant de Saussure (2001) observes that language is not a static phenomenon, but a dynamic one, as everything else in culture. One of the dichotomies by Saussure is precisely between diachrony and synchrony. The diachronic view enables the perception of linguistic changes over time and the synchronic view is an artificial section, an abstraction, in which one analyses the ever changing linguistic system as if it was a static one. Moreover it is important to consider that language changes occur not only in time but also in space. The dispersion of people through the continents, in times of primitive means of transport and communication, created the diversification of languages (and linguistics variations within the same language) over time. On the other hand, contacts and cooperation between different people have contributed to certain phenomena of linguistic convergence or hybridization, as creoles, pidgins and linguae francae. Contrary to the biblical myth, the expression "Tower of Babel", used to express linguistic confusion, could have an opposite sense: the sense of a unifying or hybridizing pressure. This is what happens with this great reversed Tower of Babel which is globalization, with its use of 
a (artificially) homogeneous global language. However like the biblical tower, the tower of globalization also results from sins, such as the suffocation of local languages and traditions. Anyway it may reduce, but has not managed to destroy language and cultural diversity, which can resist and or leave its marks in the common language and thought. This appears in convergences and divergences which generate processes of hybridization of language and culture within hegemonic languages and local cultures. Such processes may be harmonic sometimes, but also tense, conflicted, even violent.

However even within the official language of a nation there is a tension between unity and diversity. Bakhtin (2015: 39-41) distinguishes linguistic centripetal forces (forces of unification) from centrifugal forces (forces of diversity and stratification). Linguistic unification may occur spontaneously, in very small communities or in situations which require a common (though limited) linguistic comprehension between various linguistic communities, such as markets, agreements or even wars. Anyway, a more extensive and lasting unification usually results from political and economic pressures and institutional actions. Such is the case of the official language of a country, with its normative grammar. On the other hand, the centrifugal forces tend to be spontaneous, for the official language is an official pattern, a construction created and distinguished from the background of the linguistic diversity of a nation, including its popular forms.

In elaborating his theory of the novel, Bakhtin considers it the most suitable genre to explore linguistic and cultural diversity, as opposed to classical poetic genres, which aim a stylistic and ideological unity. According to Bakhtin (2015: 23-27) the limitations of stylistic studies of the novel result from the influence of a notion of a pure poetic language, inherited from the classical poetics and the philological studies. Every human being lives in a world populated by diverse linguistic and discursive varieties, but linguistic and especially discursive variety is the raw matter of the novel, in opposition to the mode of operation of classical poetic genres. Therefore Bakhtin (2015: 27) sees the novel as heterodiscursive, multistylistic and heterovocal. One should not understand such statement in the sense that the novel is a kind of linguistic patchwork, a mere juxtaposition of linguistic variations. Despite the fact that some translations of Bakhtin's thought use the term "multilingual" instead of "heterodiscursive", such feature of the novel is not just the presence formal language variants or the incorporation of regionalism and dialect terms within the national language employed by the novelist, but the dialogic confrontation of different discourses. Thus the novelist, instead of working with the absolute truth of a supreme language, works with the ideological tensions between discourses which influence and criticize each other. The "truth" emerges not from the point of view of a single discourse, but from the dialogue between different ones. One of the greatest qualities of the novelist is his deep sensitivity to otherness, and to the tensions between the views of the world expressed by each discursive and linguistic variety. According to Bakhtin, the novelist is a master of the indirect speech/discourse, a kind of literary utterance in which the voice and the point of view of the author himself does not efface the voice and view of the other conscience represented, that is, the character. In the novel, the speeches are not merely juxtaposed as simple linguistic varieties, but interact and argue as representatives of the worldview of specific groups, as discourses. Therefore, the novel represents the discursive struggle (which is not only formal, but also ideological) which characterizes the social existence of the language, especially in more complex societies.

Bakhtin states that in its heyday the novel has an overwhelming influence on the literary system, going as far as to "novelize" other genres, that is, transmits them some 
features of the novel as a dialogic heterodiscourse. But how does the novel acquire such power? Certainly that occurs not because of its pure form, but because the novel is flourishes in a society which favors the novel as a genre. According to Bakhtin, every genre (be it a literary genre or any other type of genre of discourse) stems from a pragmatic necessity. ${ }^{2}$ A genre (as well as language itself) is not invented only by the author himself (in the case of literature), or the speaker himself (in the case of other genres of discourse): it is designed by a certain community or society and developed to meet specific social demands. What a very creative author can do is to improve or even modify some traits of a given genre. Thus, a genre it is not created to meet the needs of the writer or the speaker alone, but also of a whole linguistic community which creates it. If the novel, in its several forms - after centuries of being ignored by the classic Poetics and treated as a kind rhetoric genre - acquired such an importance for western literary canon, it is because society has changed. In order to explain that it is necessary to understand what kind of social-ideological transformations produced such a positive reception of stylisticideological traits of the novel.

Bakhtin presents some explanations about the historical contexts which favor the development not only of the novel as a form, but of a "novelistic" view of the world. The most suitable periods for the novel are periods of crisis. That means periods when old beliefs and traditions begin to be questioned and a new context begin to be formed, even if that is not clearly perceived by everyone. This is the case of the Hellenistic period of Greek culture, with the decline of the polis. This is also the case of Renaissance, with its intense philosophical, scientific and economic transformations, together with the discovery of the American continent, and more intense contact between different cultures. All this contributed to destabilize medieval dogmas and may be considered the very beginning of the globalizing process. But globalization is completed by the drastic technological and political changes which have been occurring since the beginning of the twentieth century, including this contemporary phase which is usually labeled as post-modernity.

In Bakhtin's conception, Hegel's view of the novel as a bourgeois epic is valid, but insufficient to explain properly the stylistic-ideological traits of the novel. Bakhtin discover the remote sources of the novel in Socratic dialogue and Menippean satire, concerning its stylistic qualities. By associating the novel with those genres, Bakhtin has in mind not only the use of prose and the mixture of styles, but also of specific world views, less mythical and more rational, critical, ironic. It is also because of this specific view that the Socratic dialogue is invoked, although it is the product of the Attic period of Greek civilization. Socratic dialogue, according to Bakhtin is a discourse which questions ancient truths. Menippean satire, although created before, is much practiced in the Hellenistic period. The fact that its main author, Lucian, is a Syrian man (perhaps with bilingual education and hybrid culture) expresses the new political and cultural situation of the Greeks with the dissolution of the polis during the empire of Alexander continuing with Roman Empire. The same thing happens with the so-called Greek or sophistic novel, considered

2 For certain romantic conception of poetry - now popularly consolidated (though questioned) - as a purê subjective response of individual genius, it sounds strange the association of forms of ancient Greek lyric with specific social functions. For example, the encomium with a function of homage, the elegy as dirge, the epithalamium as nuptial song, the triumphal ode to celebrate the winner of a sport competition.. However, this relationship between lyrical and society confirms Bakhtin's vision of genres. The subjectivity of lyric is also a result of social demand, because at some point in the Western world, the pragmatic demands of the literary text and, even more, the lyrical text, was presented as purely aesthetic and not pragmatic, as distinguished if the other discourses of society. 
by Brandão (2005), a post-antique (post-classical) genre. Therefore, it is no coincidence the Menippean satire is rediscovered and renewed in the Renaissance, as part of the cultural revolution which begins to form the modern period.

Another key feature of the novel is its incompleteness, both in the formal sense as well as in the worldview which the novel expresses. Unlike classical genres, with their clearly defined forms, the novel is open to deep gender transformations. But the novel also expresses a non-concluded world, whose dynamics is not well expressed by other genres. With its ability of transformation, the novel is the most suitable expression of contemporary globalized, postcolonial, postmodern context. With its aptitude to renew, the novel captures the linguistic and socio-cultural conditions of globalization.

Among many other aspects that shape the complex phenomenon of globalization, there is the hegemony of certain national or colonial languages over local ones. This is actually the acceleration and expansion of a process that began with the formation of national states in Europe, later the colonial occupation, and now it happens on a global level. In all cases the tension is the same: the pressure for a unified language, homogeneous values and a hegemonic culture and technique with local traditions. In globalization all this contribute to pave the way to a more integrated global market. In this process, certainly languages and traditions may be sacrificed, but other ones can resist, though not remaining intact. One form of resistance is precisely hybridization, understood not as a simple mixture, but as a continuous process, in which the hegemonic language and techniques are combined with the local languages and traditions, as Canclini (2001) analyzes in the case of Latin America. Anyway, in spite of a power asymmetry which pressures for homogenization in such encounter of languages and cultures, none of the languages and cultures involved remains intact. This is a side effect of the globalized world: the difference emerges in the very process of homogenization.

According to Milton Santos (2008) the term "global village" may deceive, because it overlooks the fact that globalized patterns tend to cross much more easily national borders than social or regional boundaries. For example, the social contrast between rural environment and urban environments is still very strong in many parts of the world. But even in higher classes and urban populations this assimilation of global standard is selective, always resulting in a negotiation with local uses. If the benefits of globalization create a mood for cooperation, its exclusion generates processes of adaptation or even resistance. One should not forget that globalization, as it creates proper conditions to the flow of capital and goods, does not eliminate, in itself, the inequalities of capitalism. As observed by Santos, the critical perception of this situation is the first step to demand and struggle for another globalization, not just expansive, but also integrative.

It is worth analyzing what happens to the novelist's craft in such a situation: how can the novelist elaborate a critical literary expression of the globalized world. This issue is related to the raw material of the novelist: language, understood not as pure form, but as the source and bearer of a number of cultural values and ways of interpreting reality: as discourse. In the postcolonial world, colonial languages (including the present global lingua franca, which is English) were imposed and later preferred to local languages for practical and ideological reasons. But regional languages and dialects also leave their marks in hegemonic languages. This is what happens with the Brazilian Portuguese, with its Tupi and African vocabularies and several other colonial languages spread all over the world.

Political linguistic tensions are even more acute in countries where the language of the colonizer failed to destroy local languages, which are still very much used in daily life. This is the case of Angola, Mozambique, India and Indonesia, just to mention a few examples. The same process involves other elements of culture: Western bourgeois ra- 
tionalism faced with other ways of thinking; science confronted with magic worldviews; industrial technology shaking, but not always destroying local handicrafts. This is expressed, for example, in the narratives by Mozambican writer Mia Couto. His narratives written in Portuguese with many terms from local languages present the contrast between the values and the vision of the colonizer culture with the customs and local traditions and views of the world. Such a diversity may be full of striking, sometimes violent, contrasts and confrontations, is represented, for example, in Salman Rushdie's achievement, which explores the political and psychological conflicts between different cultural worlds, in characters who need to negotiate and try to conciliate or surpass different values, creating a hybrid identity, being "translated persons" (Carreira, 2004: 1). Concerning the tensions of linguistic variety in India, the narrator of Rushdie's Midnight's children says: "Language marchers demanded the partition of the state of Bombay along linguistic boundaries (...). In 1956, then, languages marched militantly through the daytime streets; by night, they rioted in my head". (Rushdie, 1995: 167).

On the other hand, the use of a lingua franca, though it enables communication, is not always enough to a deep mutual comprehension. This is illustrated in the novel Avalovara ('Avalovara'), by Brazilian writer Osman Lins (1924-1978), when the male protagonist, the aspiring writer Abel, comments his impossibility to express his geographic and cultural world to the German lady Anneliese Roos:

The language of Racine, which she uses in a literary way, dignified and even elaborate, with a pronunciation in which preciseness might be the only fault, acquires, interposed between different tongues - the language that each of us brings from our country of origin and that the other does not speak - a magical and benevolent meaning: we, without it, are two mutes. The way it opens for us, however, are limiting, and more for me than for Roos: rarely, perhaps never, can I express exactly what I am struggling to tell her.

Thus, in spite of my fervor, our conversations, fluctuating in an orbit that is neuter to a degree, equally alien to the atmosphere of the small German city where Anneliese Roos is born and that part of Brazil's Northeast which - always without success - I attempt to describe to her, illustrate, to my despair, the limitations of language and, beyond that, those of the writer, frequently the product of lands that are not too familiar. (Lins, 2002: 20)

The failed love relationship between Abel and Anneliese Roos, as the author himself states in an interview (Lins, 1979: 218) refers to a mixture of fascination of the Brazilian writer (but I could say: every writer of a colonized country) and European culture - and at the same time, the clear perception of his belonging to a different cultural world in spite of the European inheritance left by colonization. Their relationship is made of a tense eroticism that never leads to sexual fulfillment. Such a mismatch is allegoric represented by the description of the stairways of the Castle of Chambord:

I try to ask - and I desist, lacking the courage, calling on verbal help I don't possess - if she noticed the double stairway in the center of the castle at Chambord. Two people who use those two helicoids stairs at the same time, Roos, see each other but don't meet. Perhaps written there, or outlined - that is what I want to tell her and cannot manage - is the fate of many people. Including us. We're not going to go up the same stairway, Roos, no matter how much I - and even you perhaps - want the contrary. Both stairways lead to beautiful bedrooms with canopied beds. But a woman and a man could only occupy the same bed if they went up the same stairs. How can I say this and add that I'd like to sneak through the balustrade, be joined to her in every sense? (Lins, 2002: 75) 
It is important to bear in mind that globalization dislocates to a broader space the kind of linguistic tension which already existed (and still exists) in national level. During the Middle Age, local languages (labeled as “vulgar”) coexisted with Latin, but each language had its fixed place: Latin for religion, erudition and diplomacy; and vulgar languages for daily life. Latin was the language of Literature, understood as written texts and vulgar languages were the employed for much oral poetry. Parodical dialogues between the two linguistic domains appear, for example, in Carmina Burana, a collection of poems, most of them bilingual, written by a wandering clergy known as goliard monks. However the tension was not so strong because Latin was already a dead language: there was no supremacy of a certain nation (as it had happened with Latin during Roman Empire), but the supremacy of institutions: the Church and, later, the universities. The tension increases with the emergency of national languages, which is imposed in a struggle either with Latin, as well with vulgar languages. ${ }^{3}$ According to Bakhtin the translation of novels to several national languages contributed to improve the characteristics of the novel: "One can even say that European novelistic prose is born and elaborated in a process of free (reshaping) translation of the works by others". (Bakhtin, 2015: 181) ${ }^{4}$. If the translation to national languages gave material to improve the novel, on the other hand literature produced in national and local languages contributed to consolidate national and, in different level regional identities by contributing to create what Benedict Anderson denominates 'imagined communities'. (Anderson,

The tension between centripetal and centrifugal forces occurs in whichever Statenation, especially the ones compounded by a strong linguistic diversity, and it has been very acute in colonized countries, with the imposition of the colonizer's language. But, at least in lands of Catholic colonization the cathequese of indigenous people demanded, in the beginning, that the clergy learned and employed native languages. In Brazil, Jesuit priests chose and developed a lingua franca already employed by the natives, TupiGuarani, for their task of conversion. This is the beginning of a hybrid language (and in this case a hybrid poetic creation), employed in the dramatic work of Father José de Anchieta, as explained by Alfredo Bosi: 'The poet seeks, within the Tupi codes, to shape a poetic quite close the measures of the troubadour forms in their Iberian popular variants: with seven-syllable or five-syllable verses (redondilho), he forges quatrains and five-line stanzas (quintilhas) in which he creates a set of sometimes alternate, sometimes opposite rhymes.' (Bosi, 1992: 64)5. Being a native Spanish speaker who mastered Portuguese language, Anchieta felt the necessity of composing dramatic works either in Tupi or permeated by Tupi terms and faced the great difficult of adapting Tupi vocabulary to express Christian notions, thus creating a sort of theology which could not translate perfectly the original thought which he intended to teach.

Such hybridization was inhibited later in a sort of neoclassical poetics which was the result of the division between the language a literate elite and the language of common

3 The tension between the national language and dialects (which is not purely linguistic but also political) has been stronger in some countries than in other ones and lasts until nowadays, in countries where the dialects are intensely used in daily life, with some regions like Catalonia in Spain using the dialect also in official documents. As another example of such tension Claudio Marazzini informs that in the nineteenth century about $80 \%$ of Italian people were dialect speakers could not speak the standard language well. (Marazzini, 2004: 185)

4 My translation. Text in Portuguese: 'Pode-se mesmo dizer que a prosa romanesca européia nasce é é elaborada num processo de tradução livre (transformadora) das obras de outrem'. Italics by the author.

5 My translation. Text in Portuguese: 'O poeta procura, no interior dos códigos tupis, moldar uma poética bastante próxima das medidas trovadorescas em suas variantes populares ibéricas: com o verso redondilho forja quadras e quintilhas nas quais se arma um jogo de rimas ora alternadas, ora opostas. Italics by the author. 
people, which continued to be very much influenced, in vocabulary and pronunciation, by Tupi and African contributions. This division is critized by Modernist Brazilian writer Mário de Andrade (1893-1945). His narrative (called rhapsody by the author's himself) Macunaíma ("Macunaima") is probably the most Rabelasian work of Brazilian Literature. Written in a sort of colloquial Brazilian Portuguese permeated by Tupi and African terms, it presents all the characteristics analyzed by Bakhtin (1984) in Rabelais' novels: intense employment of parody, grotesque imagery and carnivalesque humor. One can say that Mário de Andrade established a dialogic relationship between erudite and popular culture in Brazilian Portuguese the same way that Rabelais had done with Latin and popular French. The chapter entitled 'Carta pras Icamiabas' ("Letter to the Icamiabas") is a parody of the letter by the scrivener Pero Vaz de Caminha informing the discovery of Brazil to the king of Portugal ${ }^{6}$. As part of the parody, the letter to the Icamiabas is addressed in an opposite direction to Caminha's letter: from the center to the periphery, but from a peripheral point of view. Written by the protagonist Macunaíma, a black ("inky black and son of the fear of the night") Indian who becomes white after bathing in a magic fountain, the letter relates the "discovery" of the city of São Paulo to the tribe of the Icamiabas. Its archaic and far-fetched style, in a "Camonian" Portuguese, contrasts contrasts with the rest of the narrative. Among other sources of strangeness, Macunaíma comments that people from São Paulo speak a language and write another one (ANDRADE, 1984, P. 66). In daily conversation, says the letter, the paulistanos speak an impure. barbarian language but as soon as they begin to write they employ "the gentle language of Camoens".

One of the most common expressions of those linguistic-ideological tensions between languages and discourses is parody. According to Bakhtin parody is not just a burlesque imitation of a known work. It is part of the procedure of stylization. In stylization there is at least two discursive consciences. As Bakhtin explains:

The heterodiscourse introduced in the novel (whatever the forms of its introduction) is the discourse of the other in the other's language, which serves to refract the expression of the author's intentions. The word of that discourse is a special double-voiced word. It serves simultaneously two speakers and expresses simultaneously two different intentions: the direct intention of the character who speaks and the refracted author's intention. In that discourse there are two voices, two senses, two expressions. Moreover these two voices are dialogically correlated, as if they knew one another (as if two replications of a dialogue knew each other and were constructed on mutual knowledge), as if they talked to each other. The double-voiced discourse is always put in a dialogue. (Bakhtin, 2010: 127) ${ }^{7}$

As two-voiced discourse, parody (or parodical stylization, as Bakhtin also calls it) differs from simple stylization because it expresses some disagreement between two linguistic consciences. According to Bakhtin, stylization, be it simple or parodic, is the

6 The letter was discovered in nineteenth century by the historian Adolfo de Varnhagen, in the intellectual mood of Brazilian Romanticism and since then has been adopted as the first literary document of Brazil.

7 My translation. Text in Portuguese: ' $O$ plurilinguismo introduzido no romance (quaisquer que sejam as formas de sua introdução), é o discurso de outrem na linguagem de outrem, que servem para refratar a expressão das intenções do autor. A palavra desse discurso é uma palavra bivocal especial. Ela serve simultaneamente a dois locutores e exprime ao mesmo tempo duas intenções diferentes: a intenção direta do personagem que fala e a intenção refrangida do autor. Nesse discurso há duas vozes, dois sentidos, duas expressões. Ademais, essas duas vozes estão dialogicamente correlacionadas, como se se conhecessem uma à outra (como se duas réplicas de um diálogo se conhecessem e fossem construídas sobre um conhecimento mútuo), como se conversassem entre si. O discurso bivocal sempre é internamente dialogizado'. Italics by the author. 
main procedure of the novelist. Stylization and parody do not refer just do identified works or passages but to the style and worldview of different discourses.

As exposed one of the remote origins of globalization and its cultural tensions is colonization. But the post-colonial phenomenon which bears the name 'globalization' includes a new factor: never migrations were so fast, massive and intense as nowadays. As Edward Said states:

For surely it is one of the unhappiest characteristics of the age to have produced more refugees, migrants, displaced persons, and exiles than ever before in history, most of them as an accompaniment to and, ironically enough, as afterthoughts of great post-colonial and imperial conflicts. As the struggle for independence produced new states and new boundaries, it also produced homeless wanderers, nomads, and vagrants, unassimilated to the emerging structures of institutional power, rejected by the established order for their intransigence and obdurate rebelliousness. And insofar as these people exist between the old and the new, between the old empire and the new state, their condition articulates the tensions, irresolutions, and contradictions in the overlapping of territories shown on the cultural map of imperialism. (Said, 1994: 332)

This causes a much more intense migration of languages (including minority languages), traditions and cultural identities. People from different origins, social classes and conditions, migrate, much more and faster than in the past. Nowadays, much more than in the past, cities are increasingly multilingual and multicultural. In big cities all over the world the official language coexists not only with regional variants, but also with the "exotic" languages. With the migration from the ex-colonies, the language the colonizer, after being imposed during centuries in the colonies, return to their original countries, but enriched with new vocabulary, accents and cultural traits. Together with language, culture also migrates; identity itself becomes hybrid, in a process which is not always peaceful.

The access for immigrant children to literacy and higher education has created the kind of writer who lives between two or more cultures. Nowadays we can find an English writer called Kazuo Ishiguro. Or a Caribbean writer of English language and Indian origin called Vidiadhar Suraiprasad Naipaul; or writers of Indian or Egyptian origin who are also influenced by western literature and express the dialogue and conflicts between cultures, like Salman Rushdie and Nagib Mahfouz. In some cases writers have a hybrid identity whose tensions they attempt to represent and criticize in their novel. This comment by Said about intellectuals in exile may also be applied for the role of the intellectual of hybrid identity:

And while it would be the rankest Panglossian dishonesty to say that the bravura performances of the intellectual exile and the miseries of the displaced person or refugee are the same, it is possible, I think, to regard the intellectual as first distilling then articulating the predicaments that disfigure modernity - mass deportation, imprisonment, population transfer, collective dispossession, and forced migration. (Said, 1994: 332-3)

The globalized world, with its complexity and its linguistic and cultural tensions, is the raw material for the contemporary novel. It is up to the novel heterodiscurso present critically such a situation, where there is much to explore. One can, for example, analyze the function and the new settings of the novel as an expression of cultural relativism in a world which has lost faith in great narratives, as stated by Jean-François Lyotard. There would also be much to approach in the role of the novel to deconstruct other identities 
such as gender and race. There is also the accentuation of a fundamental feature of novel, according to Bakhtin: the capacity of assimilation and reworking different discourses, even surpassing the border of literary discourse, as in the case of historiographical metafiction, analyzed by Linda Hutcheon, a literary form that resembles transdisciplinarity practiced in academic discourse.

For reasons of scope and unity, I limited my reflections on linguistic and some general cultural matters, bearing in mind that such a complex phenomenon as globalization involves many other problems, some of them just mentioned in this essay. I conclude by illustrating with a situation narrated in the novel Terra sonâmbula ("Sleepwalking Land") by Mozabican writer Mia Couto. The protagonists of that novel are a boy called Muidinga and an old man called Tuahir. The boy has lost his memory, but does not forget the ability of reading; the old man is illiterate but has the traditional ability of oral memory. In a country ravaged by the war, both characters resist psychologically with the help of narratives. Muidinga reads to Tuahir the diaries by Kindzu, a war victim, found in a burned bus. Those books present a hybrid text, in which the written text is permeated with oral influence, vocabulary and local magic culture. The reading aloud of Kindzu books by Muidinga is part of a broader dialogue in which Muidinga fascinates Tuahir with reading performance and Tuahir protects Muidinga with their traditional knowledge of land resources.

A better possibility of globalization is one in which the global pattern of language includes the otherness of local voices. As the novel, in Bakhtin's conception, is a hybrid form, there are cases in which the novelist, as an artist of the heterodiscouse, can expresses, by putting in dialogic confrontation the various cultural worlds which compound his characters. In such confrontations, the novelist can make use of stylization and parody - a kind of dialoguer far beyond the simple mixture of standard and local terms - thus creating hybrid discourses as an expression not only of the encounter and mutual influence of different cultures, but also of hybrid identities. It is possible to conclude that the tensions between different cultures, usually with inequality of status and power, favor the creation of parodic discourses, as well as other carnivalesque features as the ones analyzed by Bakhtin in Rabelais' novels (Bakhtin, 1984). In Brazil such procedure was called by Oswald de Andrade (1890-1954) anthropophagia: not to reject colonial language and culture neither be assimilated by it, but to create a hybrid, parodical, ironical expression. This is the kind of response given by several novelists from colonized countries. This may also be the response of writers from central multicultural countries and to the standards of globalization.

\section{References}

ANDERSON, B. Imagined communities: reflections on the origin and spread of nationalism. London: Verso, 1991.

ANDRADE, M. de. Macunaíma. Belo Horizonte: Itatiaia; Brasília: INL, Fundação Nacional Pró-Memória, 1984.

BAKHTIN, M. Os gêneros do discurso. In: Bakhtin, M. Estética da criação verbal. Tr. Paulo Bezerra. São Paulo: Martins Fontes, 2003.

. M. Teoria do romance I: a estilística. Tr. Paulo Bezerra. São Paulo: Editora 34, 2015. M. A cultura popular na Idade Média e no Renascimento: context de

François Rabelais. 
. M. Rabelais and his world. Tr. Hélène Iswolsky. Bloomington: Indiana

University Press. 1984.

BARBOSA, A. de F. O mundo globalizado: política, sociedade e economia. São Paulo: Contexto, 2007.

BAUMAN, Z. Globalização: as consequências humanas. Tr. Marcus Penchel. Rio de Janeiro: Jorge Zahar, 1999.

BHABA, H. K. O local da cultura. Tr. Myriam Ávila, Eliana Lourenço de Lima Reis, Gláucia Renate Gonçalves. Belo Horizonte: Editora da UFMG, 1998.

BOSI, A. Dialética da colonização. São Paulo: Companhia das Letras, 1992.

BRANDÃO, J. J. L. A invenção do romance: narrativa e mimese no romance grego.

Brasília: Editora da UnB, 2005.

CARREIRA, S. de S. G. 'Vestígios de transculturação em Shame, de Salman Rushdie'.

Revista eletrônica do Instituto de Humanidades. V. 3, No. 11, October/December, 2014.

Site: http://publicacoes.unigranrio.com.br/index.php/reihm/article/viewFile/463/454.

Accesso em 01.10.2014.

CANCLINI, N. G. Culturas híbridas: estratégias para entrar e sair da modernidade. São Paulo: Edusp, 2001.

COUTO, M. Terra sonâmbula: Rio de Janeiro: Nova Fronteira, 1995.

DEFARGES, P. M. La mondialisation. Paris: PUF, 2012

HALL, S. Da diáspora: identidades e mediações culturais. Belo Horizonte: Editora da UFMG, 2003.

HALL, S. A identidade cultural na pós-modernidade. Tr. Tomaz Tadeu da Silva e Guacira Lopes Louro. São Paulo: DP\&A, 1999.

HUTCHEON, L. Poética do Pós-Modernismo: História, Teoria, Ficção. Rio de Janeiro: Imago, 1991.

IANNI, O. Teorias da Globalização. Rio de Janeiro: Civilização Brasileira, 2008.

IORIS, R. R. Culturas em choque: a globalização e os desafios para a convivência multicultural. Rio de Janeiro: Annablume, 2007.

LINS, O. Avalovara. São Paulo: Companhia das Letras, 2005.

. O. Avalovara. Tr. Gregory Rabassa. New York: Dalkey Ed. 2002.

. O. Evangelho na taba: novos problemas inculturais brasileiros. Org. Julieta de

Godoy Ladeira. São Paulo: Summus Editorial, 1979.

LYOTARD, J-F. A condição pós-moderna. Rio de Janeiro: José Olympio, 1996.

MARAZZINI, C. Breve storia della lingua italiana. Bologna: Il Mulino, 2004

SAID, E. Cultura e imperialismo. Tr. Denise Bottman. São Paulo: Companhia das

Letras, 1995.

SAID, E. Culture and imperialism. New York: Vintage Books, 1994.

RUSHDIE, S. Midnight's children. London: Vintage, 1995.

SANTOS, M. Por uma outra globalização: do pensamento único à consciência universal. Rio de Janeiro: Record, 2008.

SAUSSURE, F. de. Curso de Linguística Geral. Tr. Isidoro Blikstein. São Paulo:

Cultrix, 2001.

SILVA, T. T. da (org.). Identidade e diferença: a perspectiva dos Estudos Culturais. São

Paulo: Vozes, 2008.

ORTIZ, R. Mundialização: saberes e crenças. São Paulo: Brasiliense, 2006.

. R . Mundialização e cultura. São Paulo: Brasiliense, 1994. 